\title{
Active methylotrophs in the sediments of Lonar Lake, a saline and alkaline ecosystem formed by meteor impact
}

\author{
Chakkiath Paul Antony ${ }^{1}$, Deepak Kumaresan ${ }^{2,4}$, Lucia Ferrando ${ }^{3}$, Rich Boden ${ }^{2}$, \\ Hélène Moussard $^{2}$, Ana Fernández Scavino ${ }^{3}$, Yogesh S Shouche ${ }^{1}$ and J Colin Murrell ${ }^{2}$ \\ ${ }^{1}$ Microbial Culture Collection, National Centre for Cell Science, Pune, India; ${ }^{2}$ Department of Biological \\ Sciences, University of Warwick, Coventry, UK and ${ }^{3}$ Cátedra de Microbiología, Facultad de Química, \\ Universidad de la República-Uruguay, Montevideo, Uruguay
}

\begin{abstract}
Lonar Lake is a unique saline and alkaline ecosystem formed by meteor impact in the Deccan basalts in India around $\mathbf{5 2 0 0 0}$ years ago. To investigate the role of methylotrophy in the cycling of carbon in this unusual environment, stable-isotope probing (SIP) was carried out using the onecarbon compounds methane, methanol and methylamine. Denaturing gradient gel electrophoresis fingerprinting analyses performed with heavy ${ }^{13} \mathrm{C}$-labelled DNA retrieved from sediment microcosms confirmed the enrichment and labelling of active methylotrophic communities. Clone libraries were constructed using PCR primers targeting 16S rRNA genes and functional genes. Methylomicrobium, Methylophaga and Bacillus spp. were identified as the predominant active methylotrophs in methane, methanol and methylamine SIP microcosms, respectively. Absence of mauA gene amplification in the methylamine SIP heavy fraction also indicated that methylamine metabolism in Lonar Lake sediments may not be mediated by the methylamine dehydrogenase enzyme pathway. Many gene sequences retrieved in this study were not affiliated with extant methanotrophs or methylotrophs. These sequences may represent hitherto uncharacterized novel methylotrophs or heterotrophic organisms that may have been cross-feeding on methylotrophic metabolites or biomass. This study represents an essential first step towards understanding the relevance of methylotrophy in the soda lake sediments of an unusual impact crater structure.

The ISME Journal (2010) 4, 1470-1480; doi:10.1038/ismej.2010.70; published online 17 June 2010

Subject Category: microbial ecology and functional diversity of natural habitats
\end{abstract}

Keywords: $\mathrm{C}_{1}$ compounds; Lonar Lake; soda lake; stable-isotope probing; Methylomicrobium; Methylophaga

\section{Introduction}

Bacterial assimilation of the one-carbon $\left(\mathrm{C}_{1}\right)$ compounds methane, methanol and methylamine constitutes an important component of microbe-driven food web chains in many ecosystems. Methylotrophic bacteria, phylogenetically distributed across diverse phyla, contribute significantly towards the biogeochemical cycling of carbon by facilitating the incorporation of $\mathrm{C}_{1}$ compound-derived carbon into biomass (Anthony, 1982; Chistoserdova et al., 2009). The global cycling of methane and related $\mathrm{C}_{1}$ compounds further affects important environmental phenomena related to climate change. Methanotrophs are a specialized group of methylotrophs that

Correspondence: Professor JC Murrell, Department of Biological Sciences, University of Warwick, Gibbet Hill, Coventry, CV4 7AL, UK.

E-mail: J.C.Murrell@warwick.ac.uk

${ }^{4}$ Currrent address: CSIRO Marine and Atmospheric Research, Hobart, Tasmania 7000, Australia.

Received 5 February 2010; revised 8 April 2010; accepted 11 April 2010; published online 17 June 2010 use methane as the sole carbon and energy source. These are distributed among Gammaproteobacteria (type I methanotrophs), Alphaproteobacteria (type II methanotrophs) (reviewed in Trotsenko and Murrell, 2008), filamentous methane oxidizers (Stoecker et al., 2006; Vigliotta et al., 2007) and Verrucomicrobia (Dunfield et al., 2007; Pol et al., 2007; Islam et al., 2008). Methanotrophs oxidize methane to methanol by the enzyme methane monooxygenase (MMO), present either as the particulate form (pMMO) in all characterized methanotrophs (except in the genus Methylocella (Dedysh et al., 2000)) or as the soluble form (sMMO) in some methanotrophs (Trotsenko and Murrell, 2008). Methanol dehydrogenase $(\mathrm{MDH})$ catalyzes the conversion of methanol to formaldehyde in methylotrophs (Trotsenko and Murrell, 2008, Chistoserdova et al., 2009). Probes targeting pmoA, mmoX and mxaF, genes that encode the $27 \mathrm{kDa}$ subunit of pMMO, the active site subunits of sMMO and $\mathrm{MDH}$, respectively, have been widely used for the detection of methanotrophs/methylotrophs in environmental samples (reviewed in McDonald et al., 2007). One pathway 
by which methylamine is used by methylotrophic bacteria contains methylamine dehydrogenase, but alternative pathways may also be present (Anthony, 1982; Latypova et al., 2009). Some of the marine methylotrophs involved in the metabolism of methylamine have been identified using PCR primers targeting the structural gene $(\operatorname{mau} A)$ encoding the small subunit of methylamine dehydrogenase (Neufeld et al., 2007c). Relatively few studies have focused on isolation of methylotrophs from saline and alkaline environments (Khmelenina et al., 1996; Sorokin et al., 2000; Doronina et al., 2001, 2003a,b; Kaluzhnaya et al., 2001), and the active organisms (Lin et al., 2004, 2005) and enzymes involved are poorly characterized.

Lonar crater (centred at $19^{\circ} 59^{\prime} \mathrm{N}$ and $76^{\circ} 31^{\prime} \mathrm{E}$ ) is a simple, bowl-shaped, near-circular crater formed by meteor impact (Fredriksson et al., 1973) around 52000 years ago (Sengupta et al., 1997) in the Deccan volcanic flood basalts in Maharashtra, India. Being the only well-preserved terrestrial crater to be formed entirely on basalt, it provides an excellent analogue for studying basaltic impact crater structures that are common on the surfaces of other terrestrial planets such as Mars (Hagerty and Newsom, 2003) and the Moon (Fudali et al., 1980). The crater has an average rim diameter of $1830 \mathrm{~m}$ and a rim-to-floor depth of about $150 \mathrm{~m}$ (apparent depth) (Fredriksson et al., 1973). A saline ( $\mathrm{NaCl} \sim 0.9 \%)$ and alkaline lake $(\mathrm{pH}$ 10) occupies most of the crater floor (Surakasi et al., 2007). Microbiological studies using culturedependent and -independent strategies have identified and characterized both bacterial (Kanekar et al., 1999, 2002; Nilegaonkar et al., 2002; Wani et al., 2006; Joshi et al., 2008) and archaeal (Thakker and Ranade, 2002; Surakasi, 2007; Surakasi et al., 2007) communities in the Lonar Lake water and sediments. A culture-independent study that assessed archaeal diversity in the sediments reported that most of the retrieved euryarchaeotal sequences were related to methanogens (Wani et al., 2006). Enrichment of methanogens resulted in the isolation of Methanosarcina, Methanocalculus and Methanoculleus strains (Thakker and Ranade, 2002; Surakasi et al., 2007). However, no studies have focused on the identification of active methylotrophic bacteria in sediments of the Lonar crater lake.

DNA stable-isotope probing (DNA-SIP) can reveal phylogenetic identity of previously unknown and uncultivated organisms that are metabolically active in a particular ecosystem (Radajewski et al., 2000; Dumont and Murrell, 2005). DNA-SIP successfully identified active methanotrophs and methylotrophs in Transbaikal soda lake sediments (Lin et al., 2004), Washington fresh water lake sediments (Nercessian et al., 2005), Colne estuary sediments (Moussard et al., 2009) and alkaline soils ( $\mathrm{pH}$ 9) from a Chinese coal mine (Han et al., 2009). To our knowledge, DNA-SIP experiments have not been used to characterize methylotrophs utilizing methanol and methylamine in soda lakes. In this study, we explore the diversity of active methylotrophic bacteria in saline and alkaline sediments of Lonar Lake by $\mathrm{C}_{1}$ substrates-based DNA-SIP.

\section{Materials and methods}

Sediment sampling

Surface sediment samples (top 8-12 cm) were collected in October 2008 from Lonar Lake at a depth of $6 \mathrm{~m}$. Samples were stored in sterile tubes in ice and transported to the laboratory within $24 \mathrm{~h}$. The surface temperature of sediment samples was determined on site to be $27^{\circ} \mathrm{C}$. The $\mathrm{pH}$ values measured in situ and $e x$ situ were 10.0 and $9.5 \pm 0.2$, respectively.

\section{Analysis of sediment chemical parameters}

The chemical parameters (TDS, TOC, TKN, total phosphorus as $\mathrm{PO}_{4}^{3-}, \mathrm{NO}^{3-}, \mathrm{NaCl}, \mathrm{CO}_{3}^{-}, \mathrm{Cl}^{-}, \mathrm{NH}_{3}$, $\mathrm{SO}_{4}^{2-}$, $\mathrm{Ca}, \mathrm{Co}, \mathrm{Ni}, \mathrm{B}, \mathrm{Mg}, \mathrm{K}, \mathrm{Fe}$ and $\mathrm{Cu}$ ) of wet sediment samples were analysed at a certified chemical testing laboratory (Accurate Analytical Laboratory Pvt. Limited, Pune, India) using standard methods (APHA, 1998).

\section{Stable-isotope probing}

Time-course SIP incubations were carried out in triplicate microcosms (two containing ${ }^{13} \mathrm{C}$ substrate and one containing ${ }^{12} \mathrm{C}$ substrate). Five grams of sediment were placed in sterile $120 \mathrm{ml}$ serum vials, which were then sealed with butyl rubber stoppers and injected with ${ }^{13} \mathrm{CH}_{4}\left(99 \%{ }^{13} \mathrm{C}\right.$ atom enriched; Linde gases) to yield headspace concentrations of $1 \%(\mathrm{v} / \mathrm{v})$. Similarly, labelled methanol- and methylamine-based microcosms were set up with $25 \mathrm{mM}{ }^{13} \mathrm{CH}_{3} \mathrm{OH}$ (Cambridge Isotope Laboratories, Hook, UK) and ${ }^{13} \mathrm{CH}_{3} \mathrm{NH}_{2} \mathrm{HCl}$ (Sigma, Poole, Dorset, UK). Microcosms set up with ${ }^{12} \mathrm{C}$ substrates served as control for SIP incubations. Substrate uptake was not detected in methylamine SIP microcosms (data not shown). To facilitate the active utilization of the substrate, separate methylamine SIP incubations were supplemented with $10 \%$ modified nitrate mineral medium (Kaluzhnaya et al., 2001) containing $\left(\mathrm{g} \mathrm{L}^{-1}\right)$ : $\mathrm{KNO}_{3}, 0.5 ; \mathrm{NH}_{4} \mathrm{Cl}, 0.5 ; \mathrm{KH}_{2} \mathrm{PO}_{4}, 0.35$; $\mathrm{Na}_{2} \mathrm{HPO}_{4} .12 \mathrm{H}_{2} \mathrm{O}, 0.65 ; \mathrm{NaCl}, 7.5 ; \mathrm{MgSO}_{4} .7 \mathrm{H}_{2} \mathrm{O}, 0.2$; $\mathrm{CaCl}_{2}, 0.02$. Added trace elements $\left(\mathrm{g} \mathrm{L}^{-1}\right)$ were: disodium EDTA, 5; $\mathrm{NaOH}, 0.1 ; \mathrm{ZnSO}_{4} .6 \mathrm{H}_{2} \mathrm{O}, 0.1$; $\mathrm{CaCl}_{2} \cdot 2 \mathrm{H}_{2} \mathrm{O}, 0.073 ; \mathrm{MnCl}_{2} .5 \mathrm{H}_{2} \mathrm{O}, 0.025 ; \mathrm{CoCl}_{2} \cdot 6 \mathrm{H}_{2} \mathrm{O}$, $0.005 ; \mathrm{FeSO}_{4} .7 \mathrm{H}_{2} \mathrm{O}, 0.075 ; \mathrm{CuSO}_{4} .5 \mathrm{H}_{2} \mathrm{O}, 0.002$; and ammonium molybdate pentahydrate, 0.005 . The $\mathrm{pH}$ was adjusted to 9.5 by the addition of $50 \mathrm{ml} 2 \mathrm{M}$ $\mathrm{NaHCO}_{3}$ and $10 \mathrm{ml} 1 \mathrm{M} \mathrm{Na}_{2} \mathrm{CO}_{3}$ to $1 \mathrm{l}$ medium. All incubations were carried out in the dark at $28^{\circ} \mathrm{C}$. Methane and methanol consumption was measured by gas chromatography (Agilent, CA, USA). Methylamine consumption was quantified on the basis of the methods of Fearon (1942) and Ormsby and Johnson (1950). A volume of $3.5 \mathrm{ml}$ of the solution under test was mixed with $0.25 \mathrm{ml} 80 \mathrm{~mm}$ lactose 
solution and $0.1 \mathrm{ml} 5 \mathrm{M}$ sodium hydroxide solution and incubated at $70{ }^{\circ} \mathrm{C}$ for $30 \mathrm{~min}$. The solution was cooled to room temperature and allowed to incubate for a further $60 \mathrm{~min}$. $A_{545}$ was measured and the concentration of methylamine was derived on the basis of a millimolar extinction coefficient for the pigmented imine product of $1.26 \mathrm{mM}^{-1} \mathrm{~cm}^{-1}$. SIP incubations were terminated after the consumption of $\approx 100 \mu \mathrm{mol}$ of ${ }^{13} \mathrm{CH}_{4}$ per gram sediment; $\approx 65 \mu \mathrm{mol}$ of ${ }^{13} \mathrm{CH}_{3} \mathrm{OH}$ per gram sediment; and $\approx 22 \mu \mathrm{mol}$ of ${ }^{13} \mathrm{CH}_{3} \mathrm{NH}_{2}$ per gram sediment.

\section{Community DNA extraction and density gradient fractionation}

After completion of SIP incubations with labelled $\mathrm{CH}_{4}, \mathrm{CH}_{3} \mathrm{OH}$ and $\mathrm{CH}_{3} \mathrm{NH}_{2}$, total community DNA was extracted from the respective sediment samples using a FastDNA SPIN Kit (Qbiogene Inc., Carlsbad, CA, USA). DNA concentrations were measured using a NanoDrop ND-1000 spectrophotometer. DNA fractionation and precipitation were subsequently carried out as described previously (Neufeld et al., 2007b). The buoyant density of each fraction was estimated by determining the refractive index (nD) of $\mathrm{CsCl}$ solutions with a digital refractometer (Reichert AR200, Reichert Inc., NY, USA).

PCR amplification of 16S rRNA and functional genes Aliquots comprising $\approx 30 \mathrm{ng}$ of ${ }^{13} \mathrm{C}$ or ${ }^{12} \mathrm{C}$ DNA pooled from microcosms representing each substrate were used as template in PCRs employing 16S rRNA and functional gene primers. Denaturing gradient gel electrophoresis (DGGE) and clone library analyses based on 16S rRNA genes were performed using PCR products amplified with primer sets GC341F/907R (Muyzer et al., 1998) and 27F/1492R (Weisburg et al., 1991), respectively. PCR amplifications were also carried out with primers specific for the functional genes mxaF, 1003f and 1555r (Neufeld et al., 2007c); pmoA, A189f and mb661r (Costello and Lidstrom, 1999); mmoX, 206F and 886R (Hutchens et al., 2004); and mauA, mauAf1 and mauAr1 (Neufeld et al., 2007c). All PCR reactions were carried out in a total volume of $50 \mu \mathrm{l}$ in $0.5 \mathrm{ml}$ tubes. Each PCR mix consisted of $1.5 \mathrm{mM} \mathrm{MgCl} 2,250 \mu \mathrm{M}$ dNTPs, $50 \mathrm{pmol}$ of each primer, $0.75 \mu \mathrm{l}(3.75 \mathrm{U})$ Taq DNA polymerase (Fermentas, Burlington, Ontario, Canada), $5 \mu \mathrm{l}$ $10 \times$ PCR buffer, $0.07 \%$ bovine serum albumin (BSA) and $\approx 30 \mathrm{ng}$ DNA. With the exception of the PCR for $p m o A$, all reactions were performed with an initial denaturation at $94{ }^{\circ} \mathrm{C}$ for $3 \mathrm{~min}$, followed by 35 cycles of $94{ }^{\circ} \mathrm{C}$ for $1 \mathrm{~min}$, annealing $\left(55^{\circ} \mathrm{C}\right.$ with $27 \mathrm{~F} /$ $1492 \mathrm{R}, \mathrm{GC} 341 \mathrm{~F} / 907 \mathrm{R}$ and $1003 \mathrm{f} / 1555 \mathrm{r}$; $60^{\circ} \mathrm{C}$ with 206F/886R; and $48^{\circ} \mathrm{C}$ with mauAf1/mauAr1) for $1 \mathrm{~min}$ and at $72{ }^{\circ} \mathrm{C}$ for $1 \mathrm{~min}$, followed by a final extension at $72{ }^{\circ} \mathrm{C}$ for $10 \mathrm{~min}$. For PCR with A189f/ mb661r, the following touchdown conditions were used: $94{ }^{\circ} \mathrm{C}$ for $5 \mathrm{~min}$, then 11 cycles of $1 \mathrm{~min}$ at $94{ }^{\circ} \mathrm{C}, 1 \mathrm{~min}$ at $62^{\circ} \mathrm{C}\left(-1^{\circ} \mathrm{C}\right.$ per cycle for 10 cycles $)$, $1 \mathrm{~min}$ at $72{ }^{\circ} \mathrm{C}$, followed by 25 cycles of $1 \mathrm{~min}$ at
$94{ }^{\circ} \mathrm{C}, 1 \mathrm{~min}$ at $52{ }^{\circ} \mathrm{C}, 1 \mathrm{~min}$ at $72^{\circ} \mathrm{C}$, then a final elongation step of $10 \mathrm{~min}$ at $72^{\circ} \mathrm{C}$. All PCR products were checked for size and purity on $1 \%(\mathrm{w} / \mathrm{v})$ agarose gels.

\section{DGGE analysis of 'heavy' and 'light' DNA}

PCR products generated from 'heavy' and 'light' DNA fractions after SIP were resolved by DGGE on an $8 \%$ acrylamide:bisacrylamide (37.5:1) gel with a denaturing gradient ranging from 30 to $70 \%$. Denaturant of $100 \%$ is $7 \mathrm{M}$ urea and $40 \%$ deionized formamide. Electrophoresis was carried out on a DCode universal mutation detection system (BioRad, Hercules, CA, USA) at $80 \mathrm{~V}$ for $16 \mathrm{~h}$ at $60{ }^{\circ} \mathrm{C}$. The gel was run in $1 \times$ TAE buffer and stained with Sybr Gold (Invitrogen, Paisley, UK). The most prominent bands from the DGGE gel were sequenced as previously described (Han et al., 2009).

\section{Construction of clone libraries for $16 S$ rRNA and functional genes}

PCR products were purified using the QIAquick PCR purification kit (Qiagen, Crawley, West Sussex, UK), cloned into the pGEMT easy vector (Promega, Southampton, UK) and then transformed into E. coli JM109 (Promega) following the manufacturer's instructions. A total of 100 clones (from each 16S rRNA gene library) and 50 clones (from each functional gene library) were picked for direct colony PCR, with M13F/M13R primers targeting the flanking vector sequences. PCR products were run on agarose gels with DNA ladder to confirm the correct size of the cloned inserts, and subsequently purified by PEG-NaCl precipitation (Sambrook et al., 1989) before sequencing.

\section{DNA sequencing and phylogenetic analysis}

Sequencing was performed on a 3730 DNA analyzer (Applied Biosystems, Foster City, CA, USA) using the ABI Big-Dye version 3.1 sequencing kit as per the manufacturer's instructions, with both M13F and M13R primers for all functional gene librarybased PCR products and with only M13F for $16 \mathrm{~S}$ rRNA gene library-based products (partial sequencing). The generated sequences were analysed using ChromasPro software (http://www.technelysium. com.au/ChromasPro.html) and compared with the current database of nucleotide sequences at GenBank and Ribosomal Database Project (RDP). Reference sequences were chosen on the basis of BLASTn similarities. All 16S rRNA gene sequences were checked for possible chimeric artefacts using the Pintail program (Ashelford et al., 2006) in conjunction with Bellerophon (Huber et al., 2004). Functional gene sequences were inspected for chimeras by BLASTn analysis. Multiple sequence alignments of $16 \mathrm{~S}$ rRNA gene sequences were performed with Clustal W, Version 1.8 (Thompson 
et al., 1994) and were edited manually using DAMBE (Xia and Xie, 2001) to obtain an unambiguous sequence alignment. Nucleotide distance matrices were constructed with DNADIST from PHYLIP version 3.61 (Felsenstein, 1989) using the Kimura two-parameter model (Kimura, 1980). OTUs were generated using the DOTUR program (Schloss and Handelsman, 2005) at $97 \%$ sequence similarity cutoff (for $16 \mathrm{~S}$ rRNA gene sequences) and 94\% sequence similarity cutoff (for functional gene sequences) with the furthest neighbour algorithm. A Bayesian method was used for the construction of phylogenetic tree. Before Bayesian inference analysis, a DNA substitution model for the complete data set was selected using MrModeltest2 (Posada and Crandall, 1998) and the Akaike information criterion (AIC). The model selected for the Bayesian approach for the phylogenetic tree was $\mathrm{GTR}+\mathrm{G}$ with a log likelihood ratio $(-\operatorname{lnL})=2567.2607$ and Akaike information criterion $(\mathrm{AIC})=5152.5215$. The Markov chain Monte Carlo chains were started from a random tree and run for three million generations (MrBayes version 3.0b4 (Ronquist and Huelsenbeck, 2003)). Trees were sampled every 100 generations and a consensus tree was built over all trees with the exclusion of the first 1200 trees (burn-in). Posterior probabilities were determined by constructing a $50 \%$ majority-rule tree of all trees sampled. Three separate runs were performed using the above parameters because the Bayesian approach is known to result in inflated levels of nodal support. 16S rRNA, pmoA, $m m o X$ and $m x a F$ gene sequences obtained in this study were deposited in GenBank under accession numbers GU363876-GU363923.

\section{Results}

The chemical properties of Lonar Lake sediment samples used in SIP incubations are presented in Supplementary Table S1 (See Supplementary Information). Methane, methanol and methylamine uptake rates of the sediments were calculated to be $3.3 \mu \mathrm{mol}$ $\mathrm{CH}_{4}$ day $^{-1} \mathrm{~g}^{-1}$ wet sediment, $8.3 \mu \mathrm{mol} \mathrm{CH}_{3} \mathrm{OH}$ day${ }^{1} \mathrm{~g}^{-1}$ wet sediment and $3 \mu \mathrm{mol} \mathrm{CH}_{3} \mathrm{NH}_{2}$ day $^{-1} \mathrm{ml}^{-1}$ sediment enrichment medium, respectively (Figure 1). Fractionation of sediment community DNA from labelled methane-, methanol- and methylamine-based $\mathrm{SIP}$ incubations yielded 'heavy' or ${ }^{13} \mathrm{C}$ fraction and 'light' or ${ }^{12} \mathrm{C}$ fraction with buoyant densities of 1.725 and $1.707 \mathrm{~g} \mathrm{ml}^{-1}$, respectively. The DGGE analyses of bacterial 16S rRNA gene PCR products ( $\sim 606 \mathrm{bp})$ amplified from heavy and light DNA fractions were used to confirm the success of SIP incubations. Banding patterns associated with all of the heavy fractions were distinct from those of light fractions (Figure 2), implying assimilation of each of the labelled $\mathrm{C}_{1}$ substrates by active methylotrophic populations in the sediment samples. Analysis of unlabelled $\left({ }^{12} \mathrm{C}\right)$ substrate controls further confirmed the enrichment of specific organisms in the ${ }^{13} \mathrm{C}$-exposed samples (data not shown).

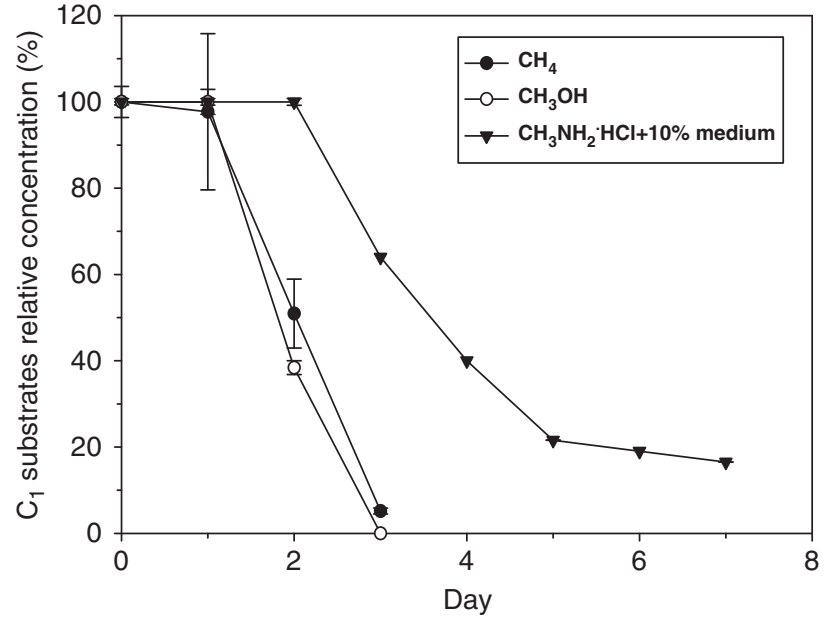

Figure $1 \mathrm{C}_{1}$ substrate utilization by Lonar Lake sediment samples. The values shown are the mean of triplicate microcosm experiments (two ${ }^{13} \mathrm{C}$ and one ${ }^{12} \mathrm{C}$ ). Standard error bars are indicated. Methane microcosms were injected with $1.2 \mathrm{ml}$ of $\mathrm{CH}_{4}$ (10080 ppmv); methanol microcosms were set up with $25 \mathrm{mM}$ $\mathrm{CH}_{3} \mathrm{OH}$ and methylamine microcosms were set up with $25 \mathrm{mM}$ $\mathrm{CH}_{3} \mathrm{NH}_{2} . \mathrm{HCl}$, in addition to $10 \%$ nutrient medium. All incubations were carried out in the dark at $28^{\circ} \mathrm{C}$. Substrate utilization rates were calculated by measuring the disappearance of each substrate during incubation.

Characterization of active methane utilizers

PCR product of the expected size $(\sim 1.4 \mathrm{~kb})$ was obtained from the methane SIP heavy DNA fraction using universal bacterial 16S rRNA gene-specific primer set 27F/1492R. Cloning of PCR product and subsequent partial sequencing ( $\sim 700 \mathrm{bp})$ of inserts generated 78 good-quality sequences. DOTUR analysis of the clone sequences identified 10 operational taxonomic units (OTUs) phylogenetically affiliated with Gammaproteobacteria (4 OTUs), Betaproteobacteria (1 OTU), Deltaproteobacteria (2 OTUs), Firmicutes (2 OTUs) and Verrucomicrobia (1 OTU) (Figure 3). BLASTn analysis showed OTUs $\mathrm{CH}_{4}$ A9, $\mathrm{CH}_{4}$ A7 7 and $\mathrm{CH}_{4}$ A8 (representing around $57 \%$ of the library) to be most closely related $(98 \%$ identity) to the $16 \mathrm{~S}$ rRNA gene sequences of 'Methylomicrobium buryatense' (AF096093), Methylomicrobium japanense (D89279) and an unpublished soda lake isolate Methylomicrobium sp. ML1 (DQ496231), respectively. The sequences of $\mathrm{CH}_{4 \_} \mathrm{A} 10$ and $\mathrm{CH}_{4} \mathrm{~A} 6$ (representing around $13 \%$ of the library) were related to the $16 \mathrm{~S}$ rRNA genes of methylotrophs Methylophaga sp. AM3Q (EU001739; 96\% identity) and Methylophilus leisingeri (AB193725; 92\% identity), respectively. For $\mathrm{CH}_{4} \mathrm{~A} 4$, $\mathrm{CH}_{4}$ A 3 and $\mathrm{CH}_{4 \_} \mathrm{A} 1$ sequences, closest cultivated neighbours were Paenibacillus sp. xw-6-66 (FJ862051; 93\% identity), Symbiobacterium thermophilum (AB004913; 90\% identity) and Kofleria flava (AJ233944; 93\% identity), respectively. The rest of the OTU sequences, $\mathrm{CH}_{4}$ A5 and $\mathrm{CH}_{4 \_} \mathrm{A} 2$, showed maximum affiliation with $16 \mathrm{~S}$ rRNA genes of 
uncultured representatives of Verrucomicrobia (AF454310; 93\% identity) and Deltaproteobacteria (EU283460; 95\% identity), respectively. From the 'heavy' fraction DGGE profile of methane SIP incubations, seven prominent bands (CH1-CH7), representing partial bacterial 16S rRNA gene products $(\sim 560 \mathrm{bp})$, were excised and sequenced (Figure 2). Sequencing DGGE bands yielded sequences that were also well represented in the $16 \mathrm{~S}$ rRNA gene clone library (Figure 3).

Primer set A189f/mb661r amplified a $472 \mathrm{bp}$ fragment of $p m o A$ gene and primer set $206 \mathrm{~F} / 886 \mathrm{R}$ amplified a $719 \mathrm{bp}$ fragment of $m m o X$ from the 'heavy' DNA fraction of methane SIP experiment. The pmoA and mmoX gene-based clone libraries ( $\sim 45$ sequences from each) generated two OTUs (PM1 and PM2) and a singleton OTU (MM1), respectively. PM1 and PM2 sequences were most closely related to the pmoA genes of Methylomicrobium japanense (AB253367; 95\% identity) and 'Methylomicrobium buryatense' (AF307139; 91\% identity), respectively. The MM1 sequence was most closely related to the $\mathrm{mmoX}$ gene of Methylomicrobium japanense (AB253366; 96\% identity).
Characterization of active methanol utilizers

A total of 79 sequences were obtained with the $16 \mathrm{~S}$ rRNA gene-based clone library and three prominent bands were sequenced after DGGE fingerprint analysis of the methanol SIP 'heavy' DNA fraction. One chimeric OTU was detected and removed from the clone library sequences. Of the 10 OTUs identified, five OTUs affiliated with Gammaproteobacteria and the rest affiliated with Alphaproteobacteria, Deltaproteobacteria, Spirochaetes, Bacteroidetes and Actinobacteria (Figure 3). The sequences of OTUs $\mathrm{CH}_{3} \mathrm{OH} \_\mathrm{B} 9$ and $\mathrm{CH}_{3} \mathrm{OH} \_\mathrm{B} 10$ (representing $81 \%$ of the library) and DGGE band OH1 showed maximum identity to the 16S rRNA genes of Methylophaga spp. (EU001739; NR_026313; 94\% identity). DGGE band $\mathrm{OH} 2$ sequence and $\mathrm{CH}_{3} \mathrm{OH} \_\mathrm{B} 8$ sequence from the library showed maximum identity of $98 \%$ to the 16S rRNA gene of Methylomicrobium sp. 4G (AF194539). The $\mathrm{CH}_{3} \mathrm{OH}$ B6 6 sequence shared $97 \%$ identity with the 16S rRNA gene of Rhodobacter sp. EL-50 (AJ605746). The $\mathrm{CH}_{3} \mathrm{OH} \_\mathrm{B} 1$ sequence lacked cultivated affiliates in the database and was most closely related to the 16S rRNA gene of uncultured Myxococcales bacterium (AB265925; 93\% identity).
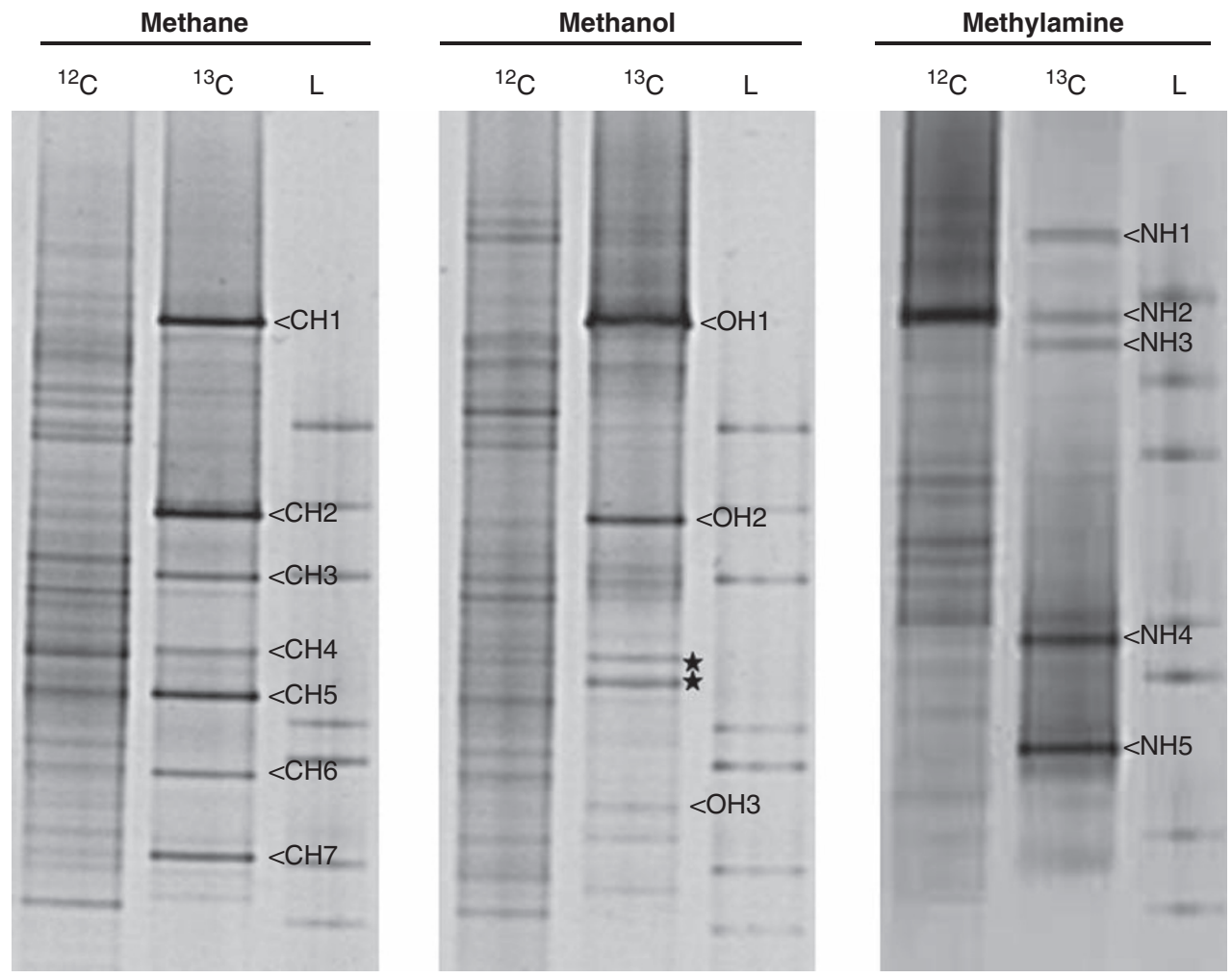

Figure 2 DGGE fingerprint profiles for ${ }^{12} \mathrm{C}$ (fraction 11) and ${ }^{13} \mathrm{C}$ DNA (fraction 7) from the ${ }^{13} \mathrm{C}$-methane, methanol and methylamine SIP incubations. Bands that were successfully sequenced are indicated and those that failed are assigned a star. L indicates DGGE ladder.

Figure 3 Bayesian phylogenetic tree showing the relationship between $16 \mathrm{~S}$ rRNA gene sequences recovered from clone libraries constructed with the 'heavy' DNA from ${ }^{13} \mathrm{C}$-methane, methanol and methylamine SIP incubations and reference sequences obtained from the NCBI database. 16S rRNA gene sequences obtained from DGGE fingerprint profiles (indicated on Figure 2) are also included. One sequence per OTU is shown and GenBank accession numbers of reference sequences are given in brackets. Bayesian posterior probabilities (based on the mean of three separate analyses) are shown. The scale bar represents $2 \%$ substitution per site. The percentage values indicate the relative abundance of each OTU in the respective clone libraries. 


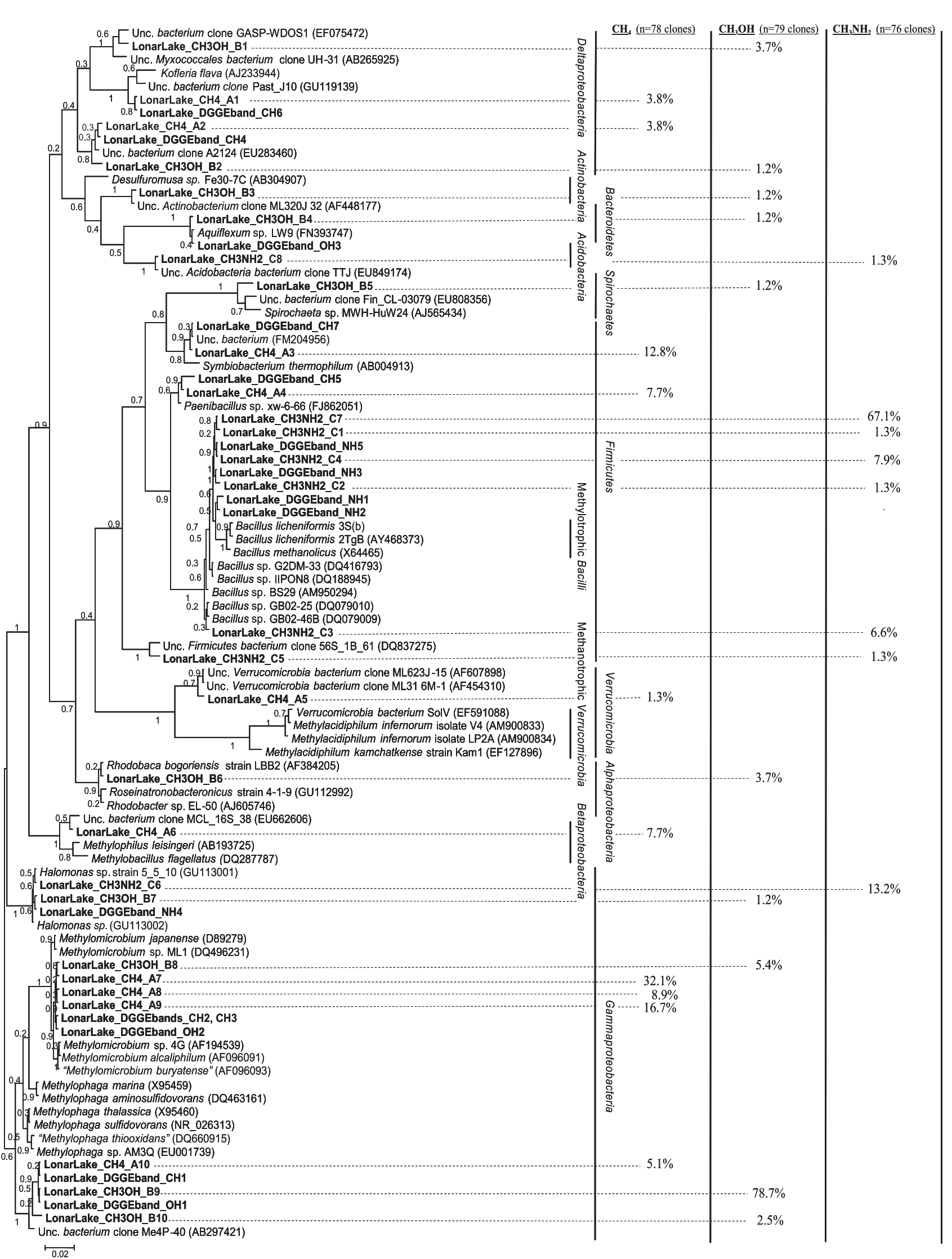


Primer set 1003f/1555r targeting mxaF yielded a PCR product of $552 \mathrm{bp}$ when 'heavy' DNA from methanol SIP was used as template. The subsequent clone library constructed generated 45 good-quality sequences that grouped into two OTUs (MX1 and MX2). The MX1 and MX2 sequences were most closely related to the mxaF genes of Methylomicrobium japanense (AB432885; 92\% identity) and Methylophaga alcalica (EU001862; 83\% identity), respectively.

Characterization of active methylamine utilizers

No methylamine uptake was detected in the methylamine SIP incubations without added nutrients (data not shown). Consumption of labelled methylamine was initiated when the microcosm sediments were supplemented with $10 \%$ nitrate mineral salts medium modified on the basis of sediment chemical properties (Supplementary Table S1). Four DGGE band sequences (Figures 2 and 3) and 76 clone library sequences were obtained from the 'heavy' DNA fraction of methylamine SIP. The library sequences grouped into a total of eight OTUs, out of which six were associated with Firmicutes and two were associated with Acidobacteria and Gammaproteobacteria (Figure 3). The majority of the DGGE band sequences (NH1, NH2, $\mathrm{NH} 3$ and NH5) and OTU sequences $\left(\mathrm{CH}_{3} \mathrm{NH}_{2} \mathrm{C} 1\right.$, $\mathrm{CH}_{3} \mathrm{NH}_{2} \mathrm{C} 2, \quad \mathrm{CH}_{3} \mathrm{NH}_{2} \mathrm{C} 3, \quad \mathrm{CH}_{3} \mathrm{NH}_{2} \mathrm{C} 4$ and $\mathrm{CH}_{3} \mathrm{NH}_{2} \mathrm{C}$ 7) representing over $84 \%$ of the library showed maximum identity of $96-98 \%$ to the $16 \mathrm{~S}$ rRNA genes of extant Bacillus spp. (DQ188945, DQ416793, DQ079010, DQ079009 and AM950294) (Figure 3). Ten sequences representing OTU $\mathrm{CH}_{3} \mathrm{NH}_{2} \mathrm{C} 6$ along with DGGE band NH4 sequence shared $100 \%$ identity with the $16 \mathrm{~S}$ rRNA gene of Halomonas sp. (GU113002).

The primer set mauAf1/mauAr1 targeting mauA did not yield amplicons from the 'heavy' DNA fraction of methylamine SIP, despite the use of PCR additives such as BSA and successful amplification of appropriate positive controls (data not shown).

\section{Discussion}

Lonar Lake represents an extreme environment with high $\mathrm{pH}$ and moderate salinity. Iron and magnesium concentrations were particularly high $\left(21.9 \mathrm{~g} \mathrm{~kg}^{-1}\right.$ sediment and $10.9 \mathrm{~g} \mathrm{~kg}^{-1}$ sediment, respectively) (Supplementary Table S1). This may be due to the Fe- and Mg-rich composition of the basalt bed rock and to meteorite iron (Schoonen et al., 2004). High total organic carbon (TOC) levels in Lonar Lake sediments could be attributed to the high primary productivity rates (up to $10 \mathrm{~g} \mathrm{~m}^{-1}$ per day) in soda lakes that often exceed other aquatic ecosystems (Jones et al., 1998). Exceptionally high total P levels may be explained by the basaltic origin of the sediments and fertilizer runoff from agricultural fields close to the crater. The Lonar crater is the only known depression in the region and hence may serve as a drain for excess runoff from anthropogenically influenced surrounding areas. However, the contribution of such natural or anthropogenic factors towards elevated phosphate and nitrate levels in the lake sediments warrants further investigation. The detected level of carbonates was relatively low but analysing the extent of contribution of other natural components towards alkalinity was beyond the scope of this study. Lonar Lake water is green throughout the year because of dense cyanobacterial blooms dominated by Arthrospira (Surakasi et al., unpublished). Decomposition of cyanobacterial biomass in soda lakes is likely to produce high quantities of methane, methanol, methylamine and dimethylsulfide (Jones et al., 1998). Organisms in soda lakes intracellularly accumulate osmolytes such as betaine and dimethylsulfoniopropionate, and their degradation by methanogens (Zavarzin et al., 1999) is likely to enrich the pool of methylated compounds. Methanotrophs and methylotrophs in such environments oxidize the $\mathrm{C}_{1}$ compounds produced, returning carbon to the food web. Methane oxidation rates are at least two-fold higher than the rates of methane formation in some soda lakes of the southern Transbaikal region (Doronina et al., 2003a). $\mathrm{C}_{1}$ intermediates (methanol, formaldehyde and formate) excreted by methanotrophs might also drive alkaline methylotrophy (Trotsenko and Khelenina, 2002).

In this study, experiments with ${ }^{13} \mathrm{CH}_{4}$ identified phylotypes closely related to the type I methanotroph Methylomicrobium (Fuse et al., 1998; Kaluzhnaya et al., 2001; Eshinimaev et al., unpublished). Methylomicrobium spp. have been isolated from several terrestrial and marine samples (Bowman et al., 1993, 1995; Sieburth et al., 1987; Fuse et al., 1998) and soda lake sediments (Kalyuzhnaya et al., 1999, 2008; Khmelenina et al., 1997, 2000; Sorokin et al., 2000; Kaluzhnaya et al., 2001). Interestingly, the haloalkaliphilic/-tolerant Methylomicrobium isolates were resistant to heat and desiccation despite the absence of cysts (Kaluzhnaya et al., 2001). Protection from such extreme conditions is mediated by the intracellular accumulation of the compatible solute ectoine (Khmelenina et al., 1997, 2000; Trotsenko et al., 2005). Methane-based DNASIP experiments with Transbaikal soda lake sediments identified the dominant methanotrophs as Methylomicrobium spp. (Lin et al., 2004). Methylomicrobium spp. have also been detected in the sediments of a fresh water lake (Lake Washington) through reverse-transcription-PCR amplification of pmoA and fae transcripts (Nercessian et al., 2005).

Methylotroph sequences related to Methylophaga thalassica and Methylophilus sp. were also retrieved in methane DNA-SIP experiments. These organisms are known to use methanol in saline and alkaline environments (reviewed in Trotsenko et al., 2007) and may have cross-fed on methanol produced by ${ }^{13} \mathrm{C}$-labelled methanotrophs. Some Methylophaga 
strains exhibit high growth rates on methanol (De Zwart et al., 1996) and this might have led to the rapid assimilation of labelled methanol by phylotypes related to Methylophaga spp. in the sediment microcosms. Surprisingly, $\sim 29 \%$ of $16 \mathrm{~S}$ rRNA gene clone library sequences and a number of DGGE band sequences had no phylogenetic affiliation with extant methanotrophs or methylotrophs. One explanation here would be the potential crossfeeding by these organisms on some labelled component from active methylotrophs. A relatively long incubation period (12 days) was necessary to permit sufficient incorporation of ${ }^{13} \mathrm{C}$-methane and this may have led to enrichment of 'cross-feeders' (reviewed in Neufeld et al., 2007a). The 16S rRNA gene sequences discussed above shared low phylogenetic identities with that of nearest cultivated neighbours in the database (90-93\%). Therefore, it is difficult to determine whether these phylotypes have been labelled by cross-feeding or these sequences represent uncharacterized methanotrophs. One of them showed maximum identity to the 16S rRNA gene of an uncultured Verrucomicrobium clone obtained from alkaline Mono Lake (Humayoun et al., unpublished). This sequence did not, however, cluster with that of thermo-acidophilic Verrucomicrobia methanotrophs (Dunfield et al., 2007; Pol et al., 2007; Islam et al., 2008) (Figure 3).

16S rRNA gene sequences from methanol SIP experiments were dominated by sequences related to Methylophaga sp. retrieved from a marine methanol SIP study (Neufeld et al., 2007c). Another possibly methylotrophic OTU (CH3OH_B10) was affiliated with the 16S rRNA gene sequence of Methylophaga sulfidovorans, a methylotroph isolated from a microbial mat using dimethylsulfide as substrate (De Zwart et al., 1996). Sequences related to Methylophaga alcalica, a haloalkaliphilic methylotroph isolated from sediments of an East Mongolian soda lake (Doronina et al., 2003b), were recovered from the mxaF clone library. Methylophaga are aerobic, moderately halophilic, nonmethane using methylotrophs, mostly isolated from marine (Janvier et al., 1985; Doronina et al., 1997; Kim et al., 2007) and soda lake ecosystems (Doronina et al., 2003a, 2003b). 16S rRNA and mxaF gene sequences related to the alkaline environment isolate Methylomicrobium sp. 4G (Kaluzhnaya et al., 2001) and Methylomicrobium japanense, respectively, were recovered from ${ }^{13} \mathrm{C}$ DNA. High methanol concentrations ranging from 5 to $7 \% \mathrm{v} / \mathrm{v}$ are known to support the growth of soda lake Methylomicrobium isolates (Kaluzhnaya et al., 2001). The presence of Rhodobacter-related clone sequences is not surprising, as Rhodobacter spp. are capable of growth on methanol (Wilson et al., 2008). The detection of a singleton OTU $\left(\mathrm{CH}_{3} \mathrm{OH}\right.$ _B7 $)$ clustering closely with Halomonas sp. (Figure 3) may be a result of cross-feeding, as some Halomonas strains are known to metabolize $\mathrm{C}_{1}$ intermediates such as formaldehyde and formate (Azachi et al., 1995). The rest of the
OTUs related to Aquiflexum sp., Spirochaeta sp. and uncultured representatives of Actinobacterium and Myxococcales again did not affiliate with known methylotrophs.

Absence of PCR amplicons for mauA confirmed the findings of DGGE fingerprinting and clone library analysis, as none of the bacteria represented by the OTUs identified (Figure 3) are known to assimilate methylamine by the methylamine dehydrogenase pathway. Methylamine can be metabolized by other pathways containing methylamineoxidase or methylamine-glutamate $\mathrm{N}$-methyl-transferase (Anthony, 1982; Chistoserdova et al., 2009; Latypova et al., 2009). The majority of sequences in the methylamine SIP 16S rRNA gene library and DGGE fingerprint profile were related to Bacillus spp. (Figure 3). Bacillus strains growing on methylamine, methanol and dimethylsulfide have been characterized (Dijkhuizen et al., 1988; Arfman et al., 1989; Anesti et al., 2005). Though the methylamine degradation pathway in the genus Bacillus is poorly characterized, all Gram-positive methylotrophs studied to date use the methylamine oxidase pathway (Chistoserdova et al., 2009). Methylamine SIP sequences from our study clustered with the $16 \mathrm{~S}$ rRNA gene sequences of both methylotrophic Bacillus strains (Arfman et al., 1992; Anesti et al., 2005) and strains isolated from contaminated soils (Desai et al., 2009; Stobdan et al., unpublished) and marine sediments (Dick et al., 2006; Sass et al., 2008) (Figure 3). This is the first SIP study to identify methylamine-utilizing Bacillus spp. directly from environmental samples. However, it may be noted here that these results may not entirely represent active participants in methylamine metabolism in situ. Methylophylaceae were implicated as active consumers of labelled methylamine in Lake Washington sediment microcosms (Nercessian et al., 2005). Although Methylophilus-related 16S rRNA gene sequences were retrieved from our methane SIP heavy fraction, no such phylotypes were detected in the methylamine SIP microcosms. Methylamine SIP studies carried out with sea water (Neufeld et al., 2007c) and estuarine sediments (Moussard et al., 2009) identified Methylophaga spp. as the dominant methylamine utilizers. Clone library and DGGE band sequences closely related to Methylophaga spp. were recovered from our methane and methanol SIP heavy fractions, but were not detected in the methylamine SIP heavy fraction. This may be due to the lack of suitable microcosm conditions for Methylophaga spp. to utilize methylamine or due to distinct substrate preferences developed as a result of competition for $\mathrm{C}_{1}$ substrates among bacterial communities of the extreme Lonar Lake environment.

In conclusion, SIP enabled the identification of Methylomicrobium, Methylophaga and Bacillus spp. as the predominant utilizers of methane, methanol and methylamine, respectively, in Lonar Lake sediments. We also detected a number of uncultured 
organisms associated with $\mathrm{C}_{1}$ metabolism and these data will assist the design of future culture-based studies to isolate novel methylotrophs from Lonar Lake.

\section{Acknowledgements}

We thank Dr Venkata Prasad Surakasi for initial discussions and help with sampling. This work was supported by the British Council UK-India Education and Research Initiative Grant SA07-061 and grants from the Natural Environment Research Council (UK) to JCM. CPA was supported by a Junior Research Fellowship from the Indian Council of Medical Research (ICMR). LF was supported by Uruguayan research grants from PDT (Programa de Desarrollo Tecnologico) and CSIC-UDELAR (Comision Sectorial de Investigacion Cientifica).

\section{References}

Anesti V, McDonald IR, Ramaswamy M, Wade WG, Kelly DP, Wood AP. (2005). Isolation and molecular detection of methylotrophic bacteria occurring in the human mouth. Environ Microbiol 7: 1227-1238.

Anthony C. (1982). The Biochemistry of Methylotrophs. Academic Press: New York.

APHA (1998). Standard Methods for the Examination of Water and Waste Water, 20th Ed., WEF: Washington DC.

Arfman N, Dijkhuizen L, Kirchhof G, Ludwig W, Schleifer KH, Bulygina ES et al. (1992). Bacillus methanolicus sp. nov., a new species of thermotolerant, methanolutilizing, endospore-forming bacteria. Int J Syst Evol Microbiol 42: 432-445.

Arfman N, Watling EM, Clement W, van Oosterwijk RJ, de Vries GE, Harder W et al. (1989). Methanol metabolism in thermotolerant methylotrophic Bacillus strains involving a novel catabolic NAD-dependent methanol dehydrogenase as a key enzyme. Arch Microbiol 152: 280-288.

Ashelford KE, Chuzhanova NA, Fry JC, Jones AJ, Weightman AJ. (2006). New screening software shows that most recent large $16 \mathrm{~S}$ rRNA gene clone libraries contain chimeras. Appl Environ Microbiol 72: 5734-5741.

Azachi M, Henis Y, Oren A, Gurevich P, Sarig S. (1995). Transformation of formaldehyde by a Halomonas sp. Can I Microbiol 41: 548-553.

Bowman JP, Sly LI, Nichols PD, Hayward, AC. (1993). Revised taxonomy of the methanotrophs: description of Methylobacter gen. nov., emendation of Methylococcus, validation of Methylosinus and Methylocystis species, and a proposal that the family Methylococcaceae includes only the group I methanotrophs. Int J Syst Bacteriol 43: 735-753.

Bowman JP, Sly LI, Stackebrandt E. (1995). The phylogenetic position of the family Methylococcaceae. Int J Syst Bacteriol 45: 182-185.

Chistoserdova L, Kalyuzhnaya MG, Lidstrom ME. (2009). The expanding world of methylotrophic metabolism. Ann Rev Microbiol 63: 477-499.

Costello AM, Lidstrom ME. (1999). Molecular characterization of functional and phylogenetic genes from natural populations of methanotrophs in lake sediments. Appl Environ Microbiol 65: 5066-5074.

Dedysh SN, Liesack W, Khmelenina VN, Suzina NE, Trotsenko YA, Semrau JD et al. (2000). Methylocella palustris gen. nov., a new methane-oxidizing acidophilic bacterium from peat bogs, representing a novel subtype of serine-pathway methanotrophs. Int $J$ Syst Evol Microbiol 50: 955-969.

Desai C, Parikh RY, Vaishnav T, Shouche YS, Madamwar D. (2009). Tracking the influence of long-term chromium pollution on soil bacterial community structures by comparative analyses of $16 \mathrm{~S}$ rRNA gene phylotypes. Res Microbiol 160: 1-9.

De Zwart JM, Nelisse PN, Kuenen JG. (1996). Isolation and characterization of Methylophaga sulfidovorans sp. nov.: an obligately methylotrophic, aerobic, dimethylsulfide oxidizing bacterium from a microbial mat. FEMS Microbiol Ecol 20: 261-270.

Dick GJ, Lee YE, Tebo BM. (2006). Manganese (II)-oxidizing Bacillus spores in Guaymas Basin hydrothermal sediments and plumes. Appl Environ Microbiol 72: 3184-3190.

Dijkhuizen L, Arfman N, Attwood MM, Brooke AG, Harder W, Watling EM. (1988). Isolation and initial characterization of thermotolerant methylotrophic Bacillus strains. FEMS Microbiol Lett 52: 209-214.

Doronina N, Darmaeva T, Trotsenko Y. (2003a). Methylophaga natronica sp. nov., a new alkaliphilic and moderately halophilic, restricted-facultatively methylotrophic bacterium from soda lake of the southern Transbaikal region. Syst Appl Microbiol 26: 382-389.

Doronina NV, Krauzova VI, Trotsenko YA. (1997). Methylophaga limanica sp. nov., a new species of moderately halophilic, aerobic, methylotrophic bacteria. Mikrobiologiya 66: 434-439.

Doronina NV, Darmaeva T, Trotsenko I. (2001). New aerobic methylotrophic isolates from the soda lakes of the southern Transbaikal. Mikrobiologiya 70: 398-404.

Doronina NV, Darmaeva TD, Trotsenko YA. (2003b). Methylophaga alcalica sp. nov., a novel alkaliphilic and moderately halophilic, obligately methylotrophic bacterium from an East Mongolian saline soda lake. Int J Syst Evol Microbiol 53: 223-229.

Dumont MG, Murrell JC. (2005). Stable isotope probing linking microbial identity to function. Nat Rev Microbiol 3: 499-504.

Dunfield PF, Yuryev A, Senin P, Smirnova AV, Stott MB, Hou $S$ et al. (2007). Methane oxidation by an extremely acidophilic bacterium of the phylum Verrucomicrobia. Nature 450: 879-882.

Fearon WR. (1942). The detection of lactose and maltose by means of methylamine. Analyst 67: 130-132.

Felsenstein J. (1989). PHYLIP-phylogeny inference package (version 3.2). Cladistics 5: 164-166.

Fredriksson K, Dube A, Milton DJ, Balasundaram MS. (1973). Lonar Lake, India: An impact crater in basalt. Science 180: 862-864.

Fudali RF, Milton DJ, Fredriksson K, Dube A. (1980). Morphology of Lonar Crater, India - comparisons and implications. Moon Planets 23: 493-515.

Fuse $\mathrm{H}$, Ohta $\mathrm{M}$, Takimura $\mathrm{O}$, Murakami K, Inoue $\mathrm{H}$, Yamaoka Y et al. (1998). Oxidation of trichloroethylene and dimethylsulfide by a marine Methylomicrobium strain containing soluble methane monooxygenase. Biosci Biotechnol Biochem 62: 1925-1931. 
Hagerty JJ, Newsom HE. (2003). Hydrothermal alteration at the Lonar Lake impact structure, India: Implications for impact cratering on Mars. Meteoritics Planetary Sci 38: 365-381.

Han B, Chen Y, Abell G, Jiang H, Bodrossy L, Zhao J et al. (2009). Diversity and activity of methanotrophs in alkaline soil from a Chinese coal mine. FEMS Microbiol Ecol 70: 196-207.

Huber T, Faulkner G, Hugenholtz P. (2004). Bellerophon: a program to detect chimeric sequences in multiple sequence alignments. Bioinformatics 20: 2317-2319.

Hutchens E, Radajewski S, Dumont MG, McDonald IR, Murrell JC. (2004). Analysis of methanotrophic bacteria in Movile Cave by stable isotope probing. Environ Microbiol 6: 111-120.

Islam T, Jensen S, Reigstad LJ, Larsen O, Birkeland NK. (2008). Methane oxidation at $55^{\circ} \mathrm{C}$ and $\mathrm{pH} 2$ by a thermoacidophilic bacterium belonging to the Verrucomicrobia phylum. Proc Natl Acad Sci USA 105: 300-304.

Janvier M, Frehel C, Grimont F, Gasser F. (1985). Methylophaga marina gen. nov., sp. nov. and Methylophaga thalassica sp. nov., marine methylotrophs. Int J Syst Bacteriol 35: 131-139.

Jones BE, Grant WD, Duckworth AW, Owenson GG. (1998). Microbial diversity of soda lakes. Extremophiles 2: 191-200.

Joshi AA, Kanekar PP, Kelkar AS, Shouche YS, Vani AA, Borgave SB et al. (2008). Cultivable bacterial diversity of alkaline Lonar Lake, India. Microb Ecol 55: 163-172.

Kaluzhnaya MG, Khmelenina VN, Eshinimaev B, Suzina N, Nikitin D, Solonin A et al. (2001). Taxonomic characterization of new alkaliphilic and alkalitolerant methanotrophs from soda lakes of the Southeastern Transbaikal region and description of Methylomicrobium buryatense sp. nov. Syst Appl Microbiol 24: $166-176$.

Kalyuzhnaya MG, Khmelenina V, Eshinimaev B, Sorokin D, Fuse H, Lidstrom M et al. (2008). Classification of halo(alkali)philic and halo(alkali)tolerant methanotrophs provisionally assigned to the genera Methylomicrobium and Methylobacter and emended description of the genus Methylomicrobium. Int J Syst Evol Microbiol 58: 591-596.

Kalyuzhnaya MG, Khmelenina VN, Suzina NE, Lysenko AM, Trotsenko YA. (1999). New methanotrophic isolates from soda lakes of the southeastern Transbaikal region. Mikrobiologiva 68: 677-685.

Kanekar PP, Nilegaonkar SS, Sarnaik SS, Kelkar AS. (2002). Optimization of protease activity of alkaliphilic bacteria isolated from an alkaline lake in India. Bioresour Technol 85: 87-93.

Kanekar PP, Sarnaik SS, Kelkar AS. (1999). Bioremediation of phenol by alkaliphilic bacteria isolated from alkaline lake of Lonar, India. J Appl Microbiol 85: 128-133.

Khmelenina VN, Eshinimaev BT, Kalyuzhnaya MG, Trotsenko I. (2000). Potential activity of methane and ammonia oxidation by methanotropic communities from soda lakes of the southern Transbaikal. Mikrobiologiva 69: 553-558.

Khmelenina VN, Kalyuzhnaya MG, Starostina NG, Suzina NE, Trotsenko YA. (1997). Isolation and characterization of halotolerant alkaliphilic methanotrophic bacteria from Tuva soda lakes. Curr Microbiol 35: 257-261.
Khmelenina VN, Starostina NG, Tsvetkova MG, Sokolov AP, Suzina NE, Trotsenko YA. (1996). Methanotrophic bacteria in the saline lakes of Ukraine and Tuva. Mikrobiologiya 65: 696-703.

Kim HG, Doronina NV, Trotsenko YA, Kim SW. (2007). Methylophaga aminisulfidivorans sp. nov., a restricted facultatively methylotrophic marine bacterium. Int $J$ Syst Evol Microbiol 57: 2096-2101.

Kimura M. (1980). A simple method for estimating evolutionary rates of base substitutions through comparative studies of nucleotide sequences. $J$ Mol Evol 16: 111-120.

Latypova E, Yang S, Wang Y-S, Wang T, Chavkin TA, Hackett $M$ et al. (2009). Genetics of the glutamatemediated methylamine utilization pathway in the facultative methylotrophic beta-proteobacterium Methyloversatalis universalis FAM5. Mol Microbiol 75: 426-439.

Lin JL, Joye SB, Scholten JC, Schafer H, McDonald IR, Murrell JC. (2005). Analysis of methane monooxygenase genes in Mono Lake suggests that increased methane oxidation activity may correlate with a change in methanotroph community structure. Appl Environ Microbiol 71: 6458-6462.

Lin JL, Radajewski S, Eshinimaev BT, Trotsenko YA, McDonald IR, Murrell JC. (2004). Molecular diversity of methanotrophs in Transbaikal soda lake sediments and identification of potentially active populations by stable isotope probing. Environ Microbiol 6: 1049-1060.

McDonald IR, Bodrossy L, Chen Y, Murrell JC. (2007). Molecular ecology techniques for the study of aerobic methanotrophs. Appl Environ Microbiol 74: 1305-1315.

Moussard H, Stralis-Pavese N, Bodrossy L, Neufeld JD, Murrell JC. (2009). Identification of active methylotrophic bacteria inhabiting surface sediment of a marine estuary. Environ Microbiol Rep 5: 424-433.

Muyzer G, Brinkhoff T, Nübel V, Santegoeds C, Schäfer H, Wawer C. (1998). Denaturing gradient gel electrophoresis (DGGE) in microbial ecology. Mol Microbial Ecol Manual 3.4.4: 1-27.

Nercessian O, Noyes E, Kalyuzhnaya MG, Lidstrom ME, Chistoserdova L. (2005). Bacterial populations active in metabolism of $\mathrm{C}_{1}$ compounds in the sediment of Lake Washington, a freshwater lake. Appl Environ Microbiol 71: 6885-6899.

Neufeld JD, Dumont MG, Vohra J, Murrell JC. (2007a). Methodological considerations for the use of stable isotope probing in microbial ecology. Microb Ecol 53: 435-442.

Neufeld JD, Schafer H, Cox MJ, Boden R, McDonald IR, Murrell JC. (2007c). Stable-isotope probing implicates Methylophaga spp. and novel Gammaproteobacteria in marine methanol and methylamine metabolism. ISME J 1: 480-491.

Neufeld JD, Vohra J, Dumont MG, Lueders T, Manefield M, Friedrich MW et al. (2007b). DNA stable-isotope probing. Nat Protoc 2: 860-866.

Nilegaonkar SS, Kanekar PP, Sarnaik SS, Kelkar AS. (2002). Production, isolation and characterization of extracellular protease of an alkaliphilic strain of Arthrobacter ramosus, MCM B-351 isolated from the alkaline lake of Lonar, India. World J Microbiol Biot 18: 785-789.

Ormsby AA, Johnson S. (1950). A colorimetric method for the determination of methylamine in urine. $J$ Biol Chem 187: 711-717. 
Pol A, Heijmans K, Harhangi HR, Tedesco D, Jetten MS, Op den Camp HJ. (2007). Methanotrophy below $\mathrm{pH} 1$ by a new Verrucomicrobia species. Nature 450: 874-878.

Posada D, Crandall KA. (1998). Modeltest: testing the model of DNA substitution. Bioinformatics 14: 817-818.

Radajewski S, Ineson P, Parekh NR, Murrell JC. (2000). Stable-isotope probing as a tool in microbial ecology. Nature 403: 646-649.

Ronquist F, Huelsenbeck JP. (2003). MrBayes 3: Bayesian phylogenetic inference under mixed models. Bioinformatics 19: 1572-1574.

Sambrook J, Fritsch E, Maniatis T. (1989). Molecular Cloning: a Laboratory Manual. Cold Spring Harbor Press: New York.

Sass AM, McKew BA, Sass H, Fichtel J, Timmis KN, McGenity TJ. (2008). Diversity of Bacillus-like organisms isolated from deep-sea hypersaline anoxic sediments. Saline Syst 4: 8.

Schloss PD, Handelsman J. (2005). Introducing DOTUR, a computer program for defining operational taxonomic units and estimating species richness. Appl Environ Microbiol 71: 1501-1506.

Schoonen M, Smirnov A, Cohn C. (2004). A perspective on the role of minerals in prebiotic synthesis. Ambio 33: 539-551.

Sengupta D, Bhandari N, Watanabe S. (1997). Formation age of Lonar meteor crater, India. Revista de Fisica Aplicada e Instrumentacao 12: 1-7.

Sieburth JM, Johnson PW, Eberhardt MA, Sieracki M, Lidstrom ME, Laux D. (1987). The first methaneoxidizing bacterium from the upper mixed layer of the deep ocean Methylomonas pelagica sp. nov. Curr Microbiol 14: 285-293.

Sorokin DY, Jones BE, Kuenen JG. (2000). An obligate methylotrophic, methane-oxidizing Methylomicrobium species from a highly alkaline environment. Extremophiles 4: 145-155.

Stoecker K, Bendinger B, Schoning B, Nielsen PH, Nielsen JL, Baranyi C et al. (2006). Cohn's Crenothrix is a filamentous methane oxidizer with an unusual methane monooxygenase. Proc Natl Acad Sci USA 103: $2363-2367$.

Surakasi VP. (2007). Diversity of Methanogenic Archaea of Lonar Lake. Ph. D. thesis University of Pune: Pune, India.
Surakasi VP, Wani AA, Shouche YS, Ranade DR. (2007). Phylogenetic analysis of methanogenic enrichment cultures obtained from Lonar Lake in India: isolation of Methanocalculus sp. and Methanoculleus sp. Microb Ecol 54: 697-704.

Thakker CD, Ranade DR. (2002). Alkalophilic Methanosarcina isolated from Lonar Lake. Curr Sci 82: 455-458.

Thompson JD, Higgins DG, Gibson TJ. (1994). CLUSTAL W: improving the sensitivity of progressive multiple sequence alignment through sequence weighting, position-specific gap penalties and weight matrix choice. Nucleic Acids Res 22: 4673-4680.

Trotsenko YA, Doronina NV, Khmelenina VN. (2005). Biotechnological potential of methylotrophic bacteria: a review of current status and future prospects. Prikl Biokhim Mikrobiol 41: 495-503.

Trotsenko YA, Doronina NV, Li T, Reshetnikov AS. (2007). Moderately haloalkaliphilic aerobic methylobacteria. Mikrobiologiya 76: 293-305.

Trotsenko YA, Khelenina VN. (2002). The biology and osmoadaptation of haloalkaliphilic methanotrophs. Mikrobiologiya 71: 149-159.

Trotsenko YA, Murrell JC. (2008). Metabolic aspects of aerobic obligate methanotrophy. Adv Appl Microbiol 63: 183-229.

Vigliotta G, Nutricati E, Carata E, Tredici SM, De SM, Pontieri P et al. (2007). Clonothrix fusca Roze 1896, a filamentous, sheathed, methanotrophic gamma-proteobacterium. Appl Environ Microbiol 73: 3556-3565.

Wani AA, Surakasi VP, Siddharth J, Raghavan RG, Patole MS, Ranade D et al. (2006). Molecular analyses of microbial diversity associated with the Lonar soda lake in India: an impact crater in a basalt area. Res Microbiol 157: 928-937.

Weisburg WG, Barns SM, Pelletier DA, Lane DJ. (1991). $16 S$ ribosomal DNA amplification for phylogenetic study. J Bacteriol 173: 697-703.

Wilson SM, Gleisten MP, Donohue TJ. (2008). Identification of proteins involved in formaldehyde metabolism by Rhodobacter sphaeroides. Microbiology 154: 296-305.

Xia X, Xie Z. (2001). DAMBE: software package for data analysis in molecular biology and evolution. J Hered 92: 371-373.

Zavarzin GA, Zhilina TN, Kevbrin VV. (1999). The alkaliphilic microbial community and its functional diversity. Mikrobiologiya 68: 503-521.

Supplementary Information accompanies the paper on The ISME Journal website (http://www.nature.com/ismej) 